\title{
太陽電池から所望の駆動力を得るための誘導機による系統連系
}

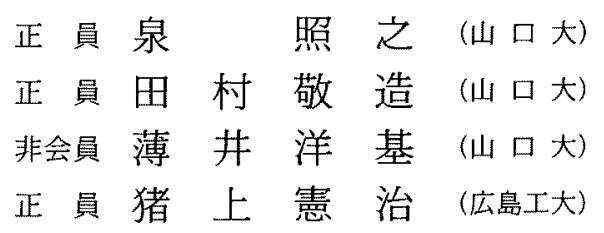

\section{Utility Interactive System by Induction Machines for Supplying the Desired Mechanical Power from Solar Batteries}

Teruyuki Izumi, Member, Keizou Tamura, Member, Hiromoto Usui, Non-member (Yamaguchi University), Kenji Inoue, Member (Hiroshima Institute of Technology)

\begin{abstract}
Solar energy is very attractive as a future power source because of an clean and inexhaustible supply. However electric power of solar batteries is variable according to weather conditions. Therefore it is stabilized by storage batteries or supplied to the utility line through an inverter for utility interconnection. These systems, however, have some problems of cost and maintenance.

This paper proposes a new utility interactive system which is composed of an induction machine A related to a solar battery through a general purpose inverter and another induction machine B interconnected with the utility line. The frequency of the inverter to drive the machine $\mathrm{A}$ is given so that the solar power can be utilized maximumly. This system can stably supply a mechanical load with the desired power by parallel operation of two induction machines even in rainy weather, and moreover regenerate extra power of the solar battery to the utility line in fine weather. This proposed system is economic and useful as a small decentralized power supply because a power filter for rejecting high frequency noises and a detector for a power failure are not necessary.
\end{abstract}

キーワード：太陽電池，系統連系，誘導機の並列運転，汎用インバー夕

\section{1. まえがき}

太陽光のエネルギーはクリーンで無尽蔵であるから将来 の電力源として注目されている。しかし, 太陽電池から得 られる電力は, 気像条件に依存して不安定であるので, そ れ単独で負荷へ安定供給できない(1) (3)。そのため, 蓄電 池を用いて安定化がなされているが(4) -(6), コストや保守 に問題がある(7)。また，太陽電池と電力系統とを連系させ るインバータの研究もある ${ }^{(8)(9)}$ 。しかし, 系統連系用イン バー夕は，そ机自身が発生する高調波成分によって電力の 品質を低下させたり, 電磁誘導障害をひき圮こすので, 電 力用ノイズフィルタを付加する必要がある。また, 配電線 の作業などでインバータが上位系統から切り離されたと き, 安全のために逆充電を防止する対策を講じなければな らないなど問題点が多い(10k11)。これらに対して, 沉用イ ンバータを用いて太陽光電力で誘導電動機を駆動するポン ピングシステムの提案がある(1)。このシステムをヒートポ
ンプ(12)(13)に適用して太陽光エネルギを熱エネルギーに変 換して蓄熱し，空調などに利用する方法が考えられる。そ の場合, 変動する太陽光電力に対してヒートポンプは一定 負荷となるので, 電力の平衡が取れず, 誘導電動機 1 台で は常時運転できない。

著者らは，汎用インバータを介して変動電力源に接続さ れた誘導電動機 $\mathrm{A}$ と, 電力系統に直接接続されたもう1 台の誘導機 B が並列運転する構成で, 変動電力源から一 定駆動力を供給するシステムを先に提案した ${ }^{(14)}$ 。このシ ステムは, 変動電力源の出力に応じて誘導機 Bが電動機 あるいは発電機となり，一定駆動力を供給しながら余剩な 電力を系統に無駄なく送ることができる。この方式は，イ ンバータが電力系統と直接接続されていないので, 上記の 電力品質の低下や逆充電の問題は生じない利点がある。先 の報告は, 太陽電池の代わりに直流定電圧源を用いての原 理の確認に留まっていた。また, インバー夕の周波数の制 御に回転数を測定する必要があり，システムが高価格にな 
るだけでなく，応答が遅い欠点があった。

本論文は, 変動電力源として太陽電池を用い, 先の提案 を発展させた新しい小規模分散型電源システムを確立する ことを目的とする。まず, 負荷の駆動動力が既知である場 合，太陽電池から最大電力を取り出すためのインバータの 指令周波数が, 太陽電池の出力と電圧の情報から決定でき ることを示している。これによって回転計が不要になり， かつ応答速度が高まり日射量の急㚆にも追従できるように なる。また，太陽電池は定電圧特性でないけれども系統と の連系によって安定に並列運転ができることを示してい る。この分散型電源システムは, 所望の駆動力を得なが ら, 強い日射時には太陽光の余剩電力を系統に供給できる 特徵をもっている。

\section{2. システムの構成}

建物の屋上には多くの誘導電動機が冷暖房や換気用など に運転されている。一方，そこには太陽エネルギーが降り 注いでいるので, 太陽光の電力で誘導電動機を駆動できれ ば，効率的である。このことに着目した分散型電源システ ムを図 1 に示す。これは 2 台の誘導機による並列運転で構 成される。太陽電池の直流電力は, 汎用インバー夕によっ て三相交流電力に変換され, 誘導電動機 I.M.A を回転 させる。この電動機は機械的負荷を担っているが,一般に 責荷の電力 $P_{M}$ は太陽光の発生電力 $P_{S}$ と一致しない。 こでもう1台の誘導機 I.M. B がこれらに機械的に結 合されて，かつスイッチSWを介して系統に連系されて いる。このB機が，日射量によって不規則に変動する太 陽光の電力 $P_{S}$ と所望の機械出力 $P_{M}$ の差埋を吸収する役 目を果している。主に舅りや夜間時における $P_{S}<P_{M}$ の場 合, 誘導機 B は電動機として機能し, 系統からの電力補 完により所望の駆動力を得る。反対に強い日射や軽負荷時 における $P_{S}>P_{M}$ の場合, 誘導機 B は発電機として働き, 所望の䁫動力を発生しながら余剰電力を系統に供給する。 これらの切り替えはインバータの周波数 $f_{A}$ によって自動 的に実現できる。さらに，PSが太陽電池の発生し得る最 大電力 $P_{S}^{*}$ に等しくなるように $f_{A}$ を決めれば, 太陽光の エネルギーが最大限に利用できる。そこで，次章でインバ 一タの周波数の決め方について述べる。

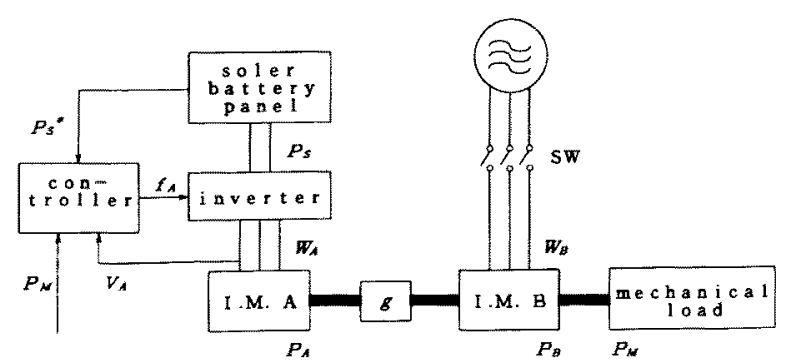

図 1 誘導機を用いる系統連系システム

Fig. 1. A new utility interactive system by using induction machines.

\section{3. インバータの周波数}

三相誘導機の一相当たりの入力電圧を $V$, 周波数を $f$, 一次巻線抵抗を $r_{1}$, 等価二次巻線抵抗を $r_{2}$, 極対数を $p$, 回転子の1秒当たりの回転数を $n$ ，すべりを $s$ ，軸出力を $P$ とする。誘導機 $\mathrm{A} ， \mathrm{~B}$ に対してこれらの記号を識別す るためにそれぞれ添字 $\mathrm{A}, \mathrm{B}$ をつけことにする。そして， これらを用いて太陽光の電力 $P_{S}$ を有効に利用しながら所 望の機械出力 $P_{M}$ を得るためのインバー夕の周波数 $f_{A}$ を 求める。

$\langle 3 \cdot 1\rangle$ 回転数情報の利用誘導機 $\mathrm{A}$ が周波数 $f_{A} O$ インバータで駆動されると, すべり $s_{A}=\left(f_{A}-p_{A} n_{A}\right) / f_{A}$ が 生じる。 $s_{A}$ が小さいときA 機の出力は

$$
P_{A}=3\left(V_{A}^{2} / r_{2 A}\right) \cdot s_{A}\left(1-s_{A}\right)
$$

で表わされる。一方, 誘導機の損失は, 無負荷損と負荷損 とからなる。前者は，機械損を無視すると，鉄損と励磁電 流による一次巻線抵抗損の和であり， $L_{0 A}$ とする。後者 沖, 負荷電流に上る二次巻線抵抗損 $\left\{s_{A} /\left(1-s_{A}\right)\right\} P_{A}$ と一 次巻線抵抗損 $\left(r_{A A} / r_{2 A}\right)\left\{s_{A} /\left(1-s_{A}\right)\right\} P_{A}$ の和である。したが って, $\mathrm{A}$ 機の入力電力 $W_{A}$ は次式で表わされる。

$$
W_{A}=\left(r_{2 A}+r_{1 A} S_{A}\right) /\left\{r_{2 A}\left(1-s_{A}\right)\right\} \cdot P_{A}+L_{0 A} \cdots \cdots \cdots(2)
$$
太陽光の電力 $P_{S}$ は, インバー夕の損失を $L_{I}$ とすると, つぎのように $\mathrm{A}$ 機の入力電力と平衡する。

$$
P_{s}=W_{A}+L_{I}
$$

$L_{0 A}$ は, 誘導機の入力電圧や周波数の関数であるが, 本方 法におけるそれらの変動範囲は小さいので，簡単のために 一定とみなす。また $L_{t}$ も，負荷によって少し変わるがそ れ自身小さいので，定数とする。この仮定のもとで，（1） 〜 (3) 式より $s_{A}$ を求めると,

$$
s_{A}=\left\{\left(\sqrt{1+4 r_{1 A}\left(P_{S}-L_{0 A}-L_{1}\right) / 3 V_{A}^{2}}-1\right\}\left(r_{2 A} / 2 r_{1 A}\right)\right.
$$

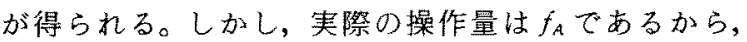
(4) 式汃ら $f_{A}$ を求めると, 次式のようになる。

$$
f_{A}=\frac{p_{A} n_{A}}{1+\left\{1-\sqrt{1+4 r_{1 A}\left(P_{S}-L_{0 A}-L_{I}\right) / 3 V_{A}^{2}}\right)\left(r_{2 A} / 2 r_{1 A}\right)}
$$

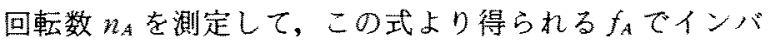
一夕を制御すれば，システムは $P_{S} に$ 応じた平衡状態にな る(14)。しかし，回転数情報をフィードバックする方法は， その測定值のばらつきを抑えるために多くの時間を要する ので, システムの応答が遅くなる欠点がある。また, 回転 計の使用がコストを上げたり，信頼性を低下させるなどの 問題点がある。したがって, 本論文では回転数の情報を利 用しない方法を考光る。

〈3・2〉機械負荷情報の利用機械的負荷の所要動力 $P_{M}$ は, 誘導機 $\mathrm{A}, \mathrm{B} の$ 出力の和に等しい。したがって, $P_{B}$ が(1)式と同様に表わされるので，

$$
3\left(V_{A}^{2} / r_{2 A}\right) \cdot s_{A}\left(1-s_{A}\right)+3\left(V_{B}^{2} / r_{2 B}\right) \cdot s_{B}\left(1-s_{B}\right)=P_{M}
$$

となる。A機と B 機絊械的に結合されていて，その速 
度比を $g$ とすると,

$$
n_{B}=g n_{A}
$$

である。これを $(6)$ 式の $s_{B}$ の中に代入して, 整理すると,

$$
\frac{V_{A}^{2}}{r_{2 A}} s_{A}+\frac{V_{B}^{2}}{r_{2 B}}\left\{g \frac{p_{B} f_{A}}{p_{A} f_{B}}-\left(g \frac{p_{B} f_{A}}{p_{A} f_{B}}\right)^{2}\left(1-s_{A}\right)\right\}=\frac{P_{M}}{3\left(1-s_{A}\right)}
$$

が導かれる。これから $f_{A}$ を求めると次式が得られる。

$$
f_{A}=f_{B} \frac{\left.1+\sqrt{1-4 r_{2 B} / V_{B}^{2}\left\{P_{M} / 3-V_{A}^{2} s_{A}\left(1-s_{A}\right) / r_{2 A}\right.}\right\}}{2 g\left(p_{B} / p_{A}\right)\left(1-s_{A}\right)}
$$

また, 誘導機 Aの負荷損を無視して, (4),（9)式に省 略算を適用すると, 付録に示すように周波数の簡易な計算 式

$$
\begin{aligned}
f_{A}^{\prime}= & \frac{f_{B}}{g\left(p_{B} / p_{A}\right)}\left\{1-\frac{\left(P_{M}+L_{0 A}+L_{I}-P_{S}\right) r_{2 B}}{3 V_{B}^{2}}\right. \\
& \left.+\frac{\left(P_{S}-L_{0 A}-L_{I}\right) r_{2 A}}{3 V_{A}^{2}}\right\} \ldots \ldots \ldots \ldots \ldots \ldots \ldots \ldots \ldots \ldots \ldots \ldots \ldots \ldots \ldots
\end{aligned}
$$

が得られる。図 2 は $P_{M}=475 \mathrm{~W}$ における太陽電池の出力 $P_{s}$ に対するインバータの周波数を示している。実線は (9)式によって，また破線は $(10)$ 式によってそれぞれ計算 された結果である。 $P_{S}$ が小さい領域では両者はほとんど 一致しているので, 誘導機の負荷損を無視した簡易式(10) でも十分に実用的であると考えられる。そこで，以下の実 験ではインバー夕の周波数として簡易式を用いることにす る。

以上, $L_{0 A}, L_{I}, r_{2 A}, r_{2 B}, p_{A}, p_{B}, f_{B}, V_{B}, g$ が既知量である から， $P_{S}$ と $V_{A}$ を測定すれば，インバータの周波数は (10)式から求められる。その場合，わずかな回転数の変動 に対して $P_{M}$ が一定であるとみなし得て，その值が既知で あることを前提としている。そのような負荷として空調用 ヒートポンプなどが考えられる。太陽電池の最大出力を $P_{S}^{*}$ とすると, $P_{S} \leqq P_{S}^{*}$ となる $P_{S}$ によるインバータの指令 周波数によって, 太陽電池の実出力は指定電力 $P_{s}$ に等し くなる。したがって, 日射量によって変動する $P_{s}^{*}$ の測定 值を(10)式の $P_{S} に$ 代入して最適周波数を決めれば，太陽 電池は常に最大電力 $P_{S}^{*}$ をインバータに供給できる。

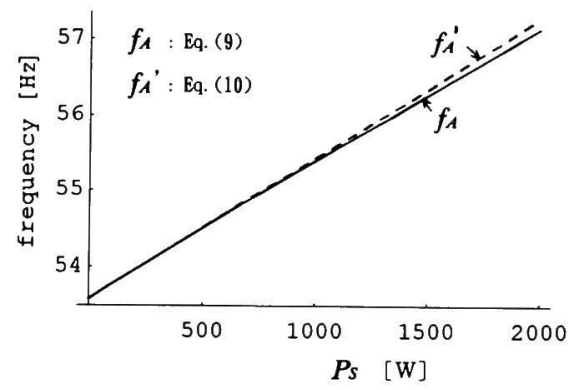

図 2 太陽光電力に対するインバータの指令周波 数

Fig. 2. Frequencies of an inverter driving a induction motor A by solar power $P_{s}$.

\section{4. 基 礎 実 験}

〈4・1〉実験装置実験で使用した誘導機 A, B は, 共に定格 $2 \mathrm{~kW}, 200 \mathrm{~V}, p_{A}=p_{B}=2$ である。これらは半径 比 $1: 0.9$ のベルト車で結合されていて， $g=10 / 9$ である。 $\mathrm{B}$ 機は $f_{B}=60 \mathrm{~Hz}, V_{B}=200 / \sqrt{3} \mathrm{~V}$ の電力系統にスイッチを 介して接続され，A 機は電圧型汎用 PWM インバータ （富士電機製の FVR-G 5) で駆動されている。汎用インパ ー夕の速度制御範囲は広いが，商用電源に接続されている 誘導機との並列運転においては, 運転周波数の変動はわず かであり, 本インバー夕の出力電圧 $V_{A}$ は直流側電圧に依 存している。この章の実験では, 直流電源としてインバー 夕の内部整流器を用い, その電圧は $300 \mathrm{~V}$ 一定とした。 一方，機械的な負荷としては直流発電機が用いられてい る。

〈4・2〉 システムの定常特性 最初に各機器の定常運 転時における損失を調べた。定格回転数近傍で, 誘導機の 無負荷損は $L_{0 A}=120 \mathrm{~W}, L_{0 B}=170 \mathrm{~W}$ ，インバー夕の損失

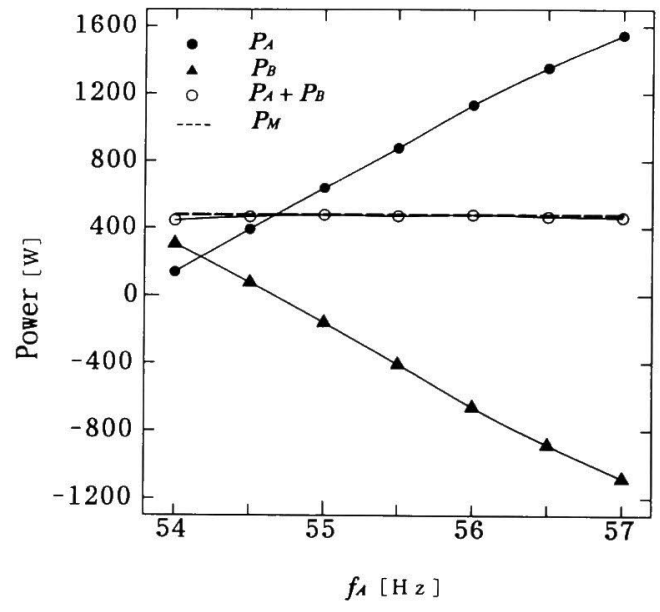

図 $3 \mathrm{~A}$ 機が定電圧源で駆動されるときの各部 の電力

Fig. 3. Powers when the machine $\mathrm{A}$ is driven by a constant voltage source.

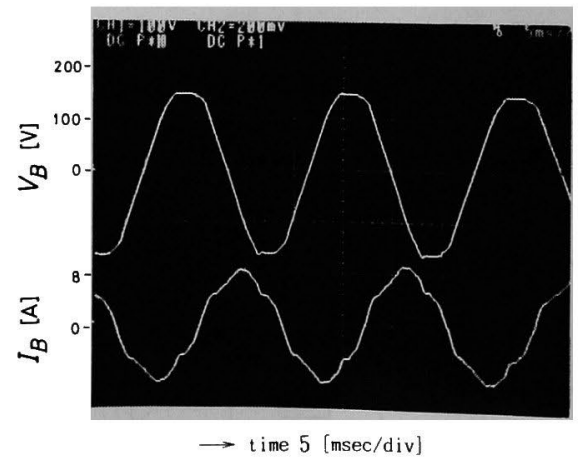

図 4 発電時の B 機の電圧・電流波形 Fig. 4. Waveforms of the voltage and current of the machine $\mathrm{B}$ at $f_{A}=57 \mathrm{~Hz}$. 


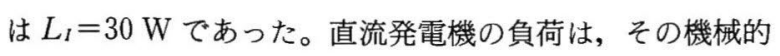
入力 $P_{M}$ が約 $470 \mathrm{~W}$ になるように調整されている。これ らの条件のもとでマニュアル操作で $f_{A}$ を変化させて, そ のときの誘導機 $\mathrm{A}, \mathrm{B}$ への入力電力 $W_{A}, W_{B}$ をそれぞれ測 定した。そして, (2)式ょり $P_{A}$, 同様な式より $P_{B}$ を求 めると, それぞれ図 3 の○、印印のよになった。 $P_{A}$ が 大きい場合, 高い $f_{A}$ でパワーが平衡する。このとき誘導 機 $\mathrm{A}$ の出力は, 機械的負荷と発電機状態である誘導機 $\mathrm{B}$ にパワーを供給している。○印は $P_{A}+P_{B}$ を表わし, 破線 の $P_{M}$ にほぼ一致している。この結果から $(6)$ 式が満たさ れていることがわかる。図 4 は $f_{A}=57 \mathrm{~Hz}$ における誘導 機 B の相電圧, 相電流の波形を示す。電流の位相が電圧 より約 120 度遅れ, B 機が発電状態であることを表わして いる。

〈4・3〉 システムの過渡特性 日射量が急激に変化し た場合を想定して, 太陽電池の出力 $P_{S}^{*}$ に対するステップ 応答を調べる。 $P_{S}^{*}$ の指令が $200 \mathrm{~W}$ から $1000 \mathrm{~W}$ に変化し たときの実験結果を図 5 に示す。 $P_{S}^{*}$ が $200 \mathrm{~W}$ のとき, $f_{A}$ $=54.0 \mathrm{~Hz}$ となり, $\mathrm{A}$ 機と $\mathrm{B}$ 機はそれぞれモー夕の状態 で機械負荷 $P_{M} \fallingdotseq 470 \mathrm{~W}$ を担っていた。 $P_{S}^{*}=1000 \mathrm{~W}$ の指 令変更によって, $f_{A}$ が $(10)$ 式より $55.5 \mathrm{~Hz}$ と決められる。 このインバータ周波数 $f_{A}$ の増加によって, 図 5 の波形か らわかるように誘導電動機 $\mathrm{A} へ$ へ力は増加し, 逆に誘 導電動機 B への入力は減少する。特にこの場合, $W_{B}$ は負 になっていることから, 誘導機 B が発電機となり, 約 220 W の余剩電力を系統に回生している。つまり, 太陽電池 の出力増加に伴って, $\mathrm{A}$ 機が太陽電池の出力を最大限利 用するように，A 機と B 機の負荷分担が変化したことを 示す。この負荷分担の変更は僅かな回転数の変化にのよっ てなされる。ところで, $W_{A}, W_{B}$ が定常状態に達するのに 約 1 秒ほど要している。この遅れの要因として, システム の慣性モーメントとディジタル電力計における電力計算時 間の影響が考えられる。前者は負荷分担の変更に伴う回転

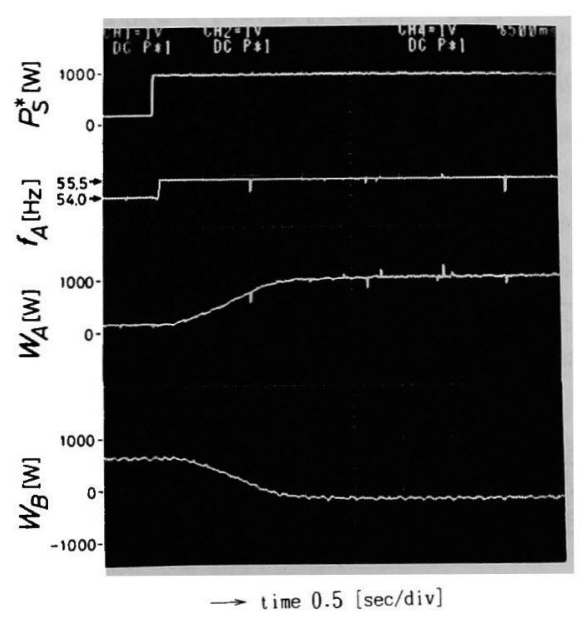

図 5 誘導機 $A$ の入力変化に対する応答 Fig. 5. Responces due to change of input power to the induction motor $\mathrm{A}$.
数の変化が少ないので十分小さいと思われる。いずれにし ても，先に報告した回転数情報を利用したフィードバック 制御 ${ }^{14)}$ に比べると，応答時間は大幅に短縮された。

\section{5. 太陽電池を用いた実験}

実験に使用した太陽電池群は, 公称開放電圧 $25 \mathrm{~V}$, 短 絡電流 $2 \mathrm{~A}$, 出力 $40 \mathrm{~W}$ のパネル 20 枚から構成され, 屋 上に設置されている。これらは 10 枚が直列に接続され, 2 組並列になっている。 4 章で使用したインバータは, こ の太陽電池で動作できるように直流電源部が改造されてい る。このため, インバータは直流電圧約 $240 \mathrm{~V}$ 付近で動 作する。したがって,これで駆動される A 機の鉄損が小 さくなり, 無負荷損は $L_{0 A} \fallingdotseq 80 \mathrm{~W}$ であった。

〈5・1〉太陽電池の最大出力の推定 太陽電池は日射 量に応じて決まる最適動作点において最大出力を取り出せ る。最適動作点を探索する種々の方法があるが,ここでは 最大出力 $P_{s}^{*}$ を知るだけで十分である。そこで, 主電源と する太陽電池と同規格の小容量のモ二タ用セルの短絡電流 から $P_{S}^{*}$ を推定する(4)。太陽電池は短絡状態付近では定電 流特性を示すので, モニタに接続した小抵抗の端子電圧 $V_{m}$ は短絡電流に比例する。 $V_{m}$ と主電源の太陽電池の最 大電力の関係は, 気温約 25 度におけるいろいろな日射量 のもとで調べると，次のような実験式で表わされた。

$$
P_{s}^{*}=113 \cdot V_{m}
$$

以後, この式を用いて $V_{m}$ の測定值から $P_{S}^{*}$ を推定する。 なお, この推定法は, 動作温度に依存するので, 本来なら 温度検出を必要とするが, 本論文では省略する。

〈5・2〉負荷分担 太陽電池が約 $700 \mathrm{~W}$ の最大出力を 安定して発生しているときのシステムの定常特性を調べ た。〈4・1〉と同様にマニュアル操作でインバー夕の周波数 $f_{A}$ を変化させて, 誘導機 $\mathrm{A}$ と B の負荷分担を求めた。図 6 に $f_{A}$ に対する各電力 $P_{A}, P_{B}, P_{A}+P_{B}, P_{M}$ のそれぞれの,

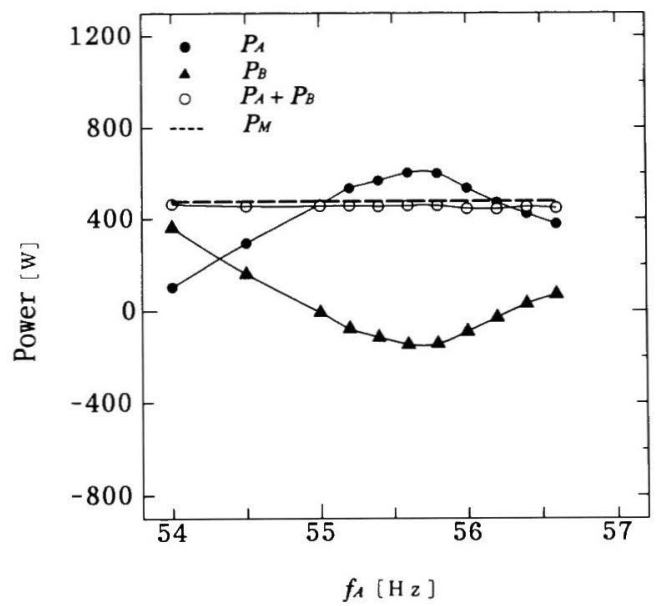

図 $6 \mathrm{~A}$ 機が太陽電池で駆動されるときの各部 の電力

Fig. 6. Powers when the machine $\mathrm{A}$ is driven by the solar batteries. 
$\boldsymbol{\Delta}, \bigcirc$, 破線で示す。これから，図 3 と同様に $P_{A}+P_{B} \fallingdotseq$ $P_{M}$ であることがわかる。A 機の出力 $P_{A}$ は, $f_{A}$ の増加と ともに増すことは図 3 と同じであるが, 約 $600 \mathrm{~W}$ を最高 にして低下している。このことから, 太陽電池を電源にす る場合, その最大電力を引き出すための最適な $f_{A}$ が存在

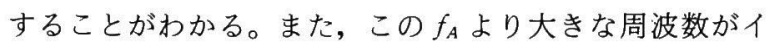
ンバータに指令されると, 太陽電池の動作点が最適点より 離れ定電流領域に入っていることを示す。この状態でも $\mathrm{B}$ 機からのパワーの供給があり，A 機は安定に運転できる。 もし, A 機単独で機械的負荷を担っている場合, $P_{A}<P_{M}$ になると $\mathrm{A}$ 機の回転は停止する。これに対して，本シス テムは，A 機のパワーの不足分を B 機が補うため，太陽 電池の動作点が定電流領域に入っても $\mathrm{A}$ 機は停止しない。

〈5・3〉自動運転 コントローラであるパソコンは, モニター用電池の $V_{m}$ とインバータの出力電圧 $V_{A}$ を取り 込む。そして, (11) 式より $P_{S}^{*}$ と $V_{A} を(10)$ 式に代入して

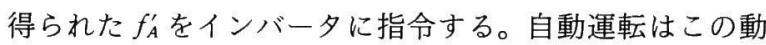
作を 0.17 秒ごとに繰り返す。日射量が急に変化する場合, 最初のサイクルでは, 測定值 $P_{S}^{*}$ は最大出力値になってい るが, $V_{A}$ は最大出力值に対応した值であるとは限らな い。しかし, $f_{A}^{\prime}$ は太陽電池の動作点を最大出力点に近づ けるように変化させるので, 何サイクルか後には, 動作点

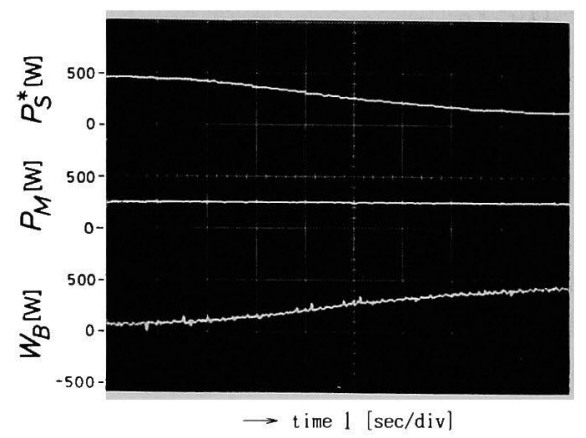

図 7 太陽光電力 $P_{s}^{*}$ の変化に対する応答 Fig. 7. Responces due to change of solar power $P_{S}^{*}$

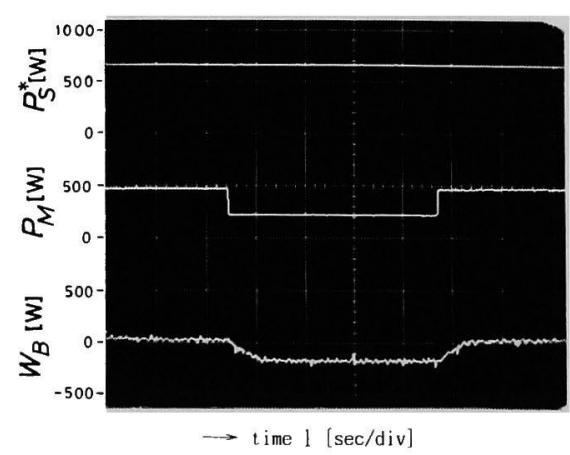

図 8 機械負荷 $P_{M}$ の変化に対する応答 Fig. 8. Responces due to change of mechanical load $P_{M}$.
が最大出力点に移動し，また $V_{A}$ も最大出力点に対応した 值となり，新しい $P_{S}^{*}$ に応じた平衡状態に達する。その根 拠は, インバー夕の出力電圧, すなわち $V_{A}$ が太陽電池の 動作点電圧に追従して変わることにある。

〈5・4〉変動特性最初に, 太陽電池の最大出力 $P_{S}^{*}$ が変化したときの様子を調べる。図 7 は，(11)式の $P_{S}^{*}$ が 約 $480 \mathrm{~W}$ から $100 \mathrm{~W}$ に減少した場合, B 機の入力 $W_{B}$ と 機械的負荷 $P_{M}$ の時間的経過を示す。 $W_{B}$ は三相電力計の 值を, $P_{M}$ は直流発電機の負荷電流の測定值から得られた 出力にその損失を加算した值を表示している。このとき, $W_{B}$ は約 $380 \mathrm{~W}$ 増加して, $P_{M}$ を $240 \mathrm{~W}$ 一定に保っている ことがわかる。この $W_{B}$ の増加は, $W_{A}$ すなわち太陽電池 の実出力 $P_{S}=W_{A}+L_{I}$ における $380 \mathrm{~W}$ の減少を意味して いる。図 7 における $W_{B}$ と $P_{S}^{*}$ のつの波形から, $P_{S}^{*}$ が 変化しても太陽電池の実出力はそれによく追従しているこ とがわかる。

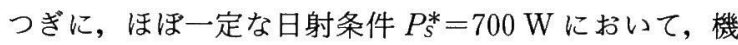
械的負荷を変化させる実験をした。図 8 の中間の波形 $P_{M}$ のように $470 \mathrm{~W}$ であった負荷を約 4 秒間 $220 \mathrm{~W}$ に減少さ せた。同図の下部の波形 $W_{B}$ は, モータとして働いていた $\mathrm{B}$ 機が， $P_{M}$ の減少の期間だけ発電機となり，200Wを系 統に回生していることを示す。これは, 太陽電池の実出力

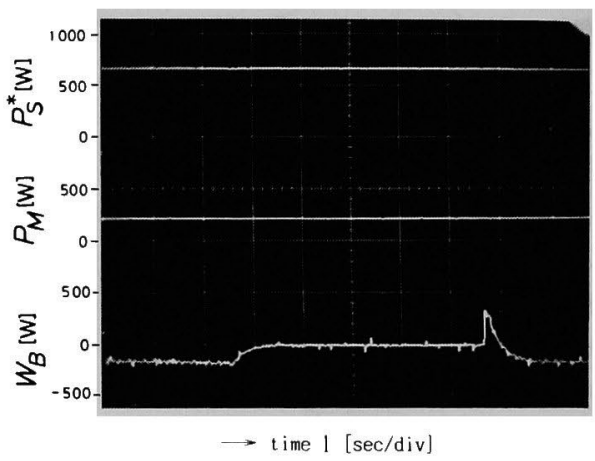

図 9 系統の停電に対する応答

Fig. 9. Responces due to an interruption of electric supply.

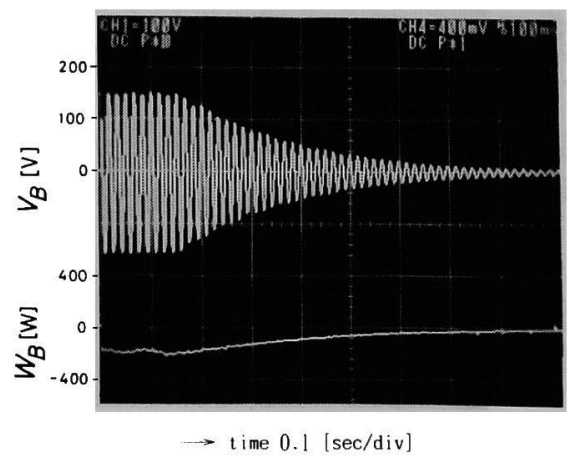

図 10 系統停電時の発電電圧波形

Fig. 10. Waveforms of the generated voltage and power after an interruption of electric supply. 
$P_{s}$ が定常的にはP*O值に保たれていることを意味する。 最後に，B機の発電中に系統が停電した場合を想定して 図 $10 \mathrm{SW}$ を開放したときのシステムの応答を調バる。 上記と同様な $P_{S}^{*}=700 \mathrm{~W}$ にいて, $P_{M}=220 \mathrm{~W}, W_{B}=$ -200W で運転中, 図 $10 \mathrm{SW}$ を約 5 秒間開放すると, 各電力は図 9 のようになった。 SW の開放時, $W_{B}$ が 0 に なるだけで， $P_{M}$ は一定であり，本システムは所望の駆動 力を負荷に供給できている。この場合太陽電池の動作点が 最適值より離れて, $P_{S} \fallingdotseq 330 \mathrm{~W}$ となり, 約 $370 \mathrm{~W}$ が無駄 になる。SWを開放した直後に括けるB機の相電圧波形 V立図10のように0になる。このことは，本システムが 太陽光電力による系統への発電を自動的に停止したことを 示す。実際の系統には，図 1 における SWとI.M.Bの間 に電気的負荷が接続されている。その負荷がある特定の静 電容量值をも場合, 誘導発電機は単独運転する可能性も ある。しかし，その単独運転を安定的に継続させることは 極めて困難であり，逆に単独運転を防止することは容易で ある。したがって, 本システムは逆充電対策必要としな いと考えられる。

\section{6. 系統連系用インバータとの比較検討}

太陽光発電用インバータを用いて系統連系させる方法が 開発されつつある。このインバー夕には, 高周波成分が系 統側に伝わらないようにノイズフィルタが内藏されたり， インパータの故障時に直流電流が采統側に流出しないよう に変圧器が設置されなければならない。そのため,このイ ンバータはモータ駆動用と異なり非常に高価になる。さら に, 系統側が停電になったとき，これを検出してインバー 夕の動作を停止させる逆充電防止機能も必要であるなど問 題点が多い。

それに対して本システムは, 系統側が停電になった場 合，図10からかかるように発電が自動的に止まるので, 上記の逆充電対策を考える必要がない。また，系統に接続 された B 機の発電時の電流波形は, 図 4 からわかるよう に高次の高調波成分を含んでいないので，ノイズフィルタ も不要である。さらにインバータが故障しても系統側に悪 い影響を及ほさないなどの利点がある。一般に誘導電動機 は始動トルクが小さいので, 始動用インバータが用いられ ている。その場合, 本システムは, 安価な誘導機 Aとコ ントローラだけを追加すればよいので，系統連系用インバ ータに比ベて極めて簡単になる。

最後に, 電力変換効率の面から本システムを検討する。 実験で使用した誘導機の容量は, 太陽電池の出力や機械負 荷に対して大き過ぎた。そのため相対的に無負荷損 $L_{0 A}$, L $0 A$ が大きかったので, 本実験での効率は高いとはいえな い。誘導機 B の損失は, 駆動力を発生する限りどの方法 でも不可避であるので問題ない。しかし，A機の損失は システムの電力効率を低下させる。日射量が極端に小さい 場合，この低下は顕著であるので，インバータの動作を停 止させる必要がある。

\section{7.あとがき}

太陽光の電力を使用して所望の駆動力を誘導電動機で発 生させる小規模分散型電源システムを提案した。これは， 太陽光で駆動される誘導電動機 A と系統に值接接続され た誘導機 Bの並列運転によって実現されている。太陽電 池を用いて本システムを検証して, 以下の結墖を得た。

（1）太陽電池が発生している電力を有効に利用するた めに誘導機 $\mathrm{A}$ を駆動するインバー夕の周波数を求めた。

（2）太陽電池の接続が直流電源部の簡単な改造で実現 されるので，安価な沉用インバータが利用でる。

（3）日射が弱いときでもB機の援助によって所望の 駆動力を安定に得ることができた。

（4）日射が強いときや要求歌動パワーが小さいとき, 太陽光の電力が B 機を通じて系統に回生できた。

（5）系統が停電したらB機の発生電圧は自動的に0 となり，また，インバ一夕の故障が系統に影響をおよはささ ないなど分散電源として䐗ましい特性を有している。

(平成 6 年 5 月 23 日受付, 同 7 年 1 月 5 日再受付)

文献

（1）黑川・山上・谷：「太隄光発電システムの各種システム楆成とる の分類!電子技術総合研究所舆報, 50,96 (昭 61)

(2)黑川：「大陽光発電 $の$ 最近の開発動间」, 電学諭 D, 108, 106 (昭 63-2)

（3）長谷川・外山・内息・西條：「太陽䨮池・誘導発電機ハイブリッ

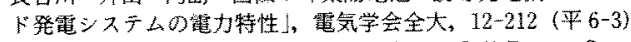

(4) H. Matsuo \& F. Kurokawa: "New Solar Cell Power Supply System Using a Boost Type Bidirectional DC-DC Converter", IEEE Trans. on Industrial Electronics, IE-31, 51 (1984-2)

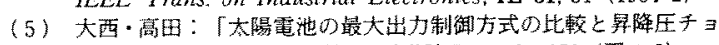
ッパ回路を用いた制御特性」, 電学論 D, 112, 250 (平4-3)

（6）川崎：「蓄電池を用いた太陽光発電ジステムの可能発電力」, 電 学論 $\mathrm{D}, 112,244$ (平 $4-3$ )

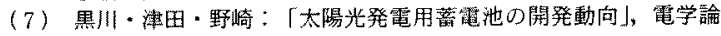
$\mathrm{B}, 110,91$ (平 $2-2$ )

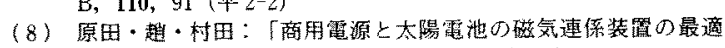

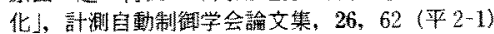

（9）野中・袈装丸・山踦：「篻相PWM電硫型イン゙バータに上る太陽 光発電㯖系システム」, 電学論 $\mathrm{B}, 112,439$ (平 4-5)

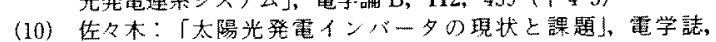
112,950 (平 $4-12$ )

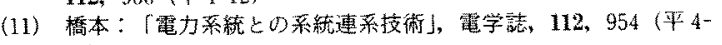
12)

（12）尾崎・矢部：「省エホルボ一に頁献するヒートポンブ」, 電学論 B, 111,827 (平 $3-8$ )

(13) A. Domijan, O. Hancock, \& C. Maytrott: "A Study and Evaluation of Power Electronic Based Adjustable Speed Motor Drives for Air Conditioners and Heat Pumps with an Example Utility Case Study of the Florida Power and Light Com. pany", IEEE Trans, on Energy Conversion, 7, 396 (1992-9)

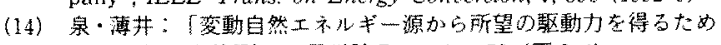

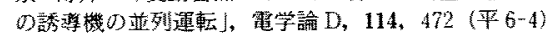

\section{付 録}

\section{〈簡易なインバー夕設定周波数の導出〉}

(4)式は, Taylor 展開された後, $r_{A}$ が小さいので高 次項を無視して

$$
s_{A}=\frac{r_{2 A}}{3 V_{A}^{2}}\left(P_{S}-L_{0 A}-L_{l}\right)
$$

と簡略化される。同様沈 $(9)$ 式も $r_{2 B}$ が小さいので， 


$$
f_{A}=f_{B} \frac{1-\left(r_{2 B} / 3 V_{B}^{2}\right)\left\{P_{M}-3 V_{A}^{2} s_{A}\left(1-s_{A}\right) / r_{2 A}\right\}}{g\left(p_{B} / p_{A}\right)\left(1-s_{A}\right)}
$$

となる。分子の \{\} 内の第 2 項目が $(1)$ 式より $P_{A}$ に, さ らに $P_{A}$ が $(2),(3)$ 式の $\mathrm{A}$ 機の負荷損の無視より $P_{S}$ $-L_{0 A}-L_{I}$ となるので, (付 2 ) 式は

$$
f_{A}=f_{B} \frac{1-\left(r_{2 B} / 3 V_{B}^{2}\right)\left(P_{M}+L_{0 A}+L_{I}-P_{S}\right)}{g\left(p_{B} / p_{A}\right)\left(1-s_{A}\right)} \cdots \text {. (付 3) }
$$

と表わされる。またこの式は， $s_{A} \ll 1$ の関係を用いてさら に省略算を施すと,つぎのようになり，これを $f_{A}^{\prime}$ とする。

$$
f_{A}^{\prime}=\frac{f_{B}}{g\left(p_{B} / p_{A}\right)}\left\{1-\frac{r_{2 B}}{3 V_{B}^{2}}\left(P_{M}+L_{0 A}+L_{I}-P_{S}\right)+s_{A}\right\}
$$

結局，(付 4)式に(付 1) 式を代入すると(10)式が導かれる。

泉照之（正員）昭和 46 年広島大学工学部電子工学科卒

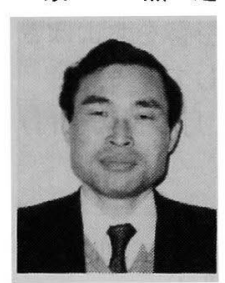
業。同年 4 月通産省工業技術院九州工業技術試 験所に入所。平成元年 4 月より山口大学工学部 電気電子工学科助教授, 現在にいたる。太陽光 発電やロボットの省エネルギー運転の研究に従 事。工学博士。

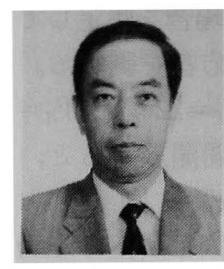

（非会員）昭和 49 年京都大学大学院工学研究科 博士課程化学工学専攻修了。現在, 山口大学工 学部応用化学工学科教授。工学博士。
猪 上 憲 治 (正員) 昭和 42 年 3 月広島工業大学工学部電気 工学科卒業。同年 4 月同大学助手, 現在, 同大 学助教授。主として, ブラシレス同期機, 誘導 機に関する研究に従事。

田村 敬 造 (正員) 平成 6 年山口大学工学部電気工学科卒

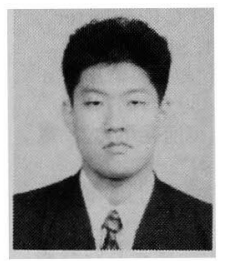

業。現在, 同大学大学院工学研究科博士前期課 程に在学中。太陽光発電を利用したシステムに 関する研究に従事。 